\title{
Melanosis Coli: Case Report
}

\section{Melanozis Koli: Olgu Sunumu}

\author{
(1) Selma Şengiz Erhan1, (1) Gamze Kulduk1, (1) Damla Karabıyık1, (1) Mehmet Gökçeimam² \\ 1 İstanbul Okmeydanı Training and Research Hospital, Clinic of Pathology, İstanbul, Turkey \\ 2İstanbul Kartal Dr. Lütfi Kırdar Kartal Training and Research Hospital, Clinic of General Surgery, İstanbul, Turkey
}

\section{HIIIII| ABSTRACT}

Melanosis coli is an incidental benign finding characterized by the deposition of dark brown pigment in the colonic mucosa. The cause of this situation is due to long-term laxative use. We report a female patient who underwent surgery for colon adenocarcinoma and diagnosed as melanosis coli during histopathological examination.

Keywords: Colon, melanosis coli, tumor

\section{||||||||||| ÖZ}

Melanozis koli kolonik mukozanın siyah kahverengi pigmentasyonuyla karakterize benign bir hastalıktır. Uzun süreli konstipasyon yakınmaları olan olgularda laksatiflerin kullanımı sonucu daha sık izlenmektedir. Biz burada sigmoid kolon tümörü nedeniyle opere edilen ve histopatolojik inceleme sonrası adenokarsinom ve melanozis koli tanısı alan kadın hastayı sunmayı amaçladık.

Anahtar Kelimeler: Kolon, melanozis koli, tümör

\section{Introduction}

Melanosis coli is characterized by increased macrophages localized in the colonic mucosa, with black-brown pigment in their cytoplasm. It is asymptomatic and is often incidentally detected during colonoscopic or histopathological examination. ${ }^{1}$ Histochemically, the intracellular pigment cross-reacts with Fontana-Masson and is lipofuscin-like. Ultrastructural studies have shown that this pigment is formed by the destruction of apoptotic colonic epithelial cells. ${ }^{2}$ Melanosis coli is detected during the investigation of the causes of constipation due to malnutrition especially in the elderly. Recently, the incidence has increased as a result of colonoscopic examinations. ${ }^{1,3}$

\section{Case Report}

A 56-year-old woman was admitted to the emergency department with the complaints of constipation, nausea, vomiting and abdominal pain, and she was hospitalized with pre-diagnosis of colon tumor. In the emergency ultrasonographic examination, abdomen could not be evaluated due to abdominal gas distension. Computed tomography revealed that the distended appearance in the right and descending colon was sharply terminated in the proximal segment of the sigmoid colon, and that from this point, it was found that there was significant thickening in the colon wall, serosa irregularity and dirty appearance in the paracolic fatty planes along the intestinal segment of $3.5 \mathrm{~cm}$ in length. The patient was operated on with the preliminary diagnosis of primary colon tumor. Macroscopic examination of the left column resection material revealed a $2.4 \times 0.8 \mathrm{~cm}$ ulcerous tumor that partially obliterated the lumen. It was noted that the mucosa remaining proximal to the tumor and all serosal surfaces were diffuse black-brown except for the tumor and the distal mucosa (Figure 1). In histopathological examination of the tumor, moderately differentiated adenocarcinoma composed of cribriform adenoid structures 
invading the pericolorectal adipose tissue was seen and adenocarcinoma metastasis was detected in three of the 13 lymph nodes dissected from the pericolic fat. In the sections of non-tumoral black mucosal areas, macrophages in the lamina propria and the presence of black-brown pigment in the cytoplasm of macrophages were noted (Figure 2a, b). Histochemical study showed positive staining of these pigments with Fontana-Masson, while staining with iron was not observed (Figure 2c). It was learned that the patient had a history of laxative use with anthraquinone for three months in the preoperative period due to constipation. The patient was diagnosed with "adenocarcinoma" and "melanosis coli". Clinical follow-up of the patient who received six cycles of chemotherapy after the operation continues.

\section{Discussion}

Although there is no clear information about the incidence of melanosis coli, rates ranging from $1-59.5 \%$ have been reported. ${ }^{4,5}$ It is more common in women as in our case and in older age. ${ }^{1,6}$ Pigment can be observed more intensively in the cecum and ascending colon than in the distal column. ${ }^{1,2}$ In our case, melanosis coli was detected in the sigmoid colon. The use of laxatives, especially laxatives containing anthraquinone, is a well-known cause for melanosis coli. It can usually develop after 4-9 months of use. With the discontinuation of use, it may recede within

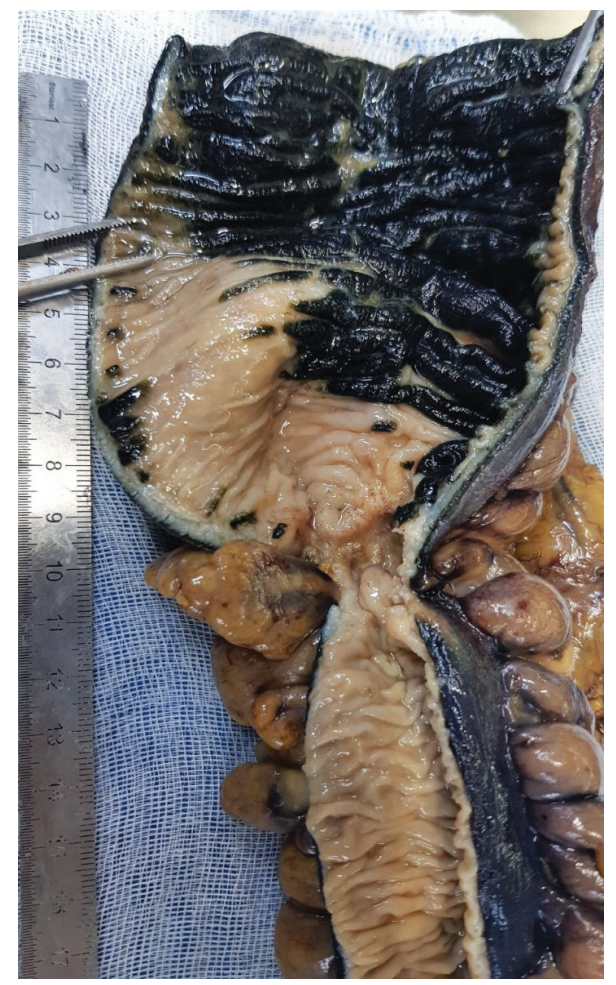

Figure 1. Tumor tissue and diffuse black-brown mucosa proximal to tumor tissue months. ${ }^{7}$ It can be seen in varying rates in inflammatory bowel disease, colonic diverticulum, chronic diarrhea, nonsteroidal anti-inflammatory drug use, colorectal polyps and tumors. ${ }^{5,8}$ It has been reported in the literature that it is frequently associated with colonic polyps., ${ }^{5,9}$ In one study, it was emphasized that pigment-free polyps were more easily detected in endoscopic examination because of the black-brown color of the mucosa. ${ }^{5}$ These polyps may include adenomatous polyps, which may include carcinoma focus. Biopsy from the non-pigmented areas in the recognition and exclusion of these lesions is also among the recommendations..$^{10}$ In a study that reported the association with non-neoplastic polyps that contain pigment, the toxic effect resulting in the destruction of the apoptotic colonic epithelial cells was claimed to cause the development of the colorectal polyps, as well as melanosis coli. ${ }^{8}$ Although no polyp was detected in our case, it was observed that there was no macroscopic and microscopic pigment accumulation in ulcerated tumor tissue in accordance with the literature. Diffuse black-brown pigment was observed on the mucosa and serosal surface of the tumor proximal. Melanosis coli is a benign and reversible lesion. However, the findings in the studies on whether there is a relationship between colorectal tumors seen in similar age groups are controversial. In some of the studies, an increased risk for the tumor was reported in cases with melanosis coli, while some did not suggest a relationship. ${ }^{6,9}$ In conclusion, as in our case, melanosis coli can be defined as a lesion that may arise as a result of long-

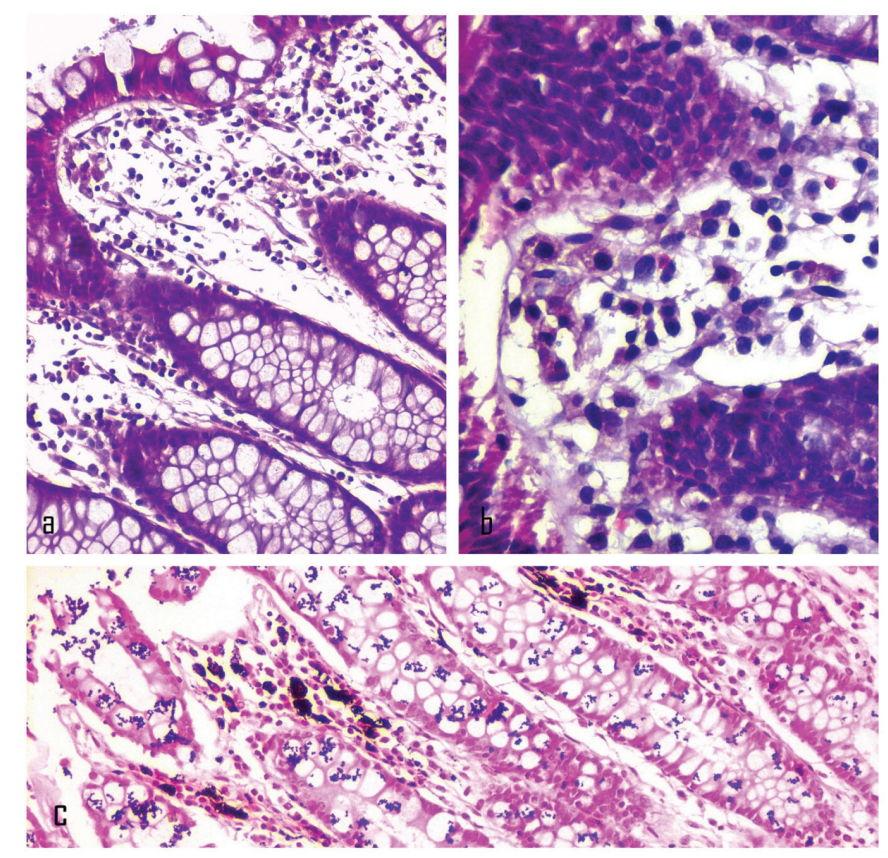

Figure 2. Macrophage clusters in the mucosa and the presence of blackbrown pigments in the cytoplasm of macrophages [a: hematoxylin and eosin (H\&E), x200, b: H\&E, x400). Positive staining with FontanaMasson c: x200] 
term laxative use in order to correct the changing bowel habit due to tumor.

\section{Ethics}

Informed Consent: Was taken.

Peer-review: External peer-reviewed.

\section{Authorship Contributions}

Surgical and Medical Practices: S.Ş.E., G.K., D.K., M.G., Concept: S.Ş.E., G.K., Design: S.Ş.E., G.K., D.K., M.G., Data Collection or Processing: S.S..E., G.K., M.G., Analysis or Interpretation: S.Ş.E., G.K., D.K., M.G., Literature Search: S.Ş.E., G.K., D.K., Writing: S.Ş.E., G.K.

Conflict of Interest: No conflict of interest was declared by the authors.

Financial Disclosure: The authors declared that this study received no financial support.

\section{References}

1. Nesheiwat Z, Al Nasser Y. Melanosis Coli. StatPearls [Internet]. Treasure Island (FL): StatPearls Publishing; 2019.
2. Freeman HJ. "Melanosis" in the small and large intestine. World J Gastroenterol 2008;14:4296-4299.

3. Ahasan HN, Khan MA, Mahbub S, Alam MB, Miah MT, Gupta RD, et al. Melanosis Coli - An Atypical Presentation. J Medicine 2010;11:183-185.

4. Biernacka-Wawrzonek D, Stepka M, Tomaszewska A, Ehrmann-Josko A, Chojnowska N, Zemlak M, et al. Melanosis coli in patients with colon cancer. Prz Gastroenterol 2017;12:22-27.

5. Wang S, Wang Z, Peng L, Zhang Xl, Li J, Yang Y, Hu B, et al. Gender, age, and concomitant diseases of melanosis coli in China: a multicenter study of 6,090 cases. PeerJ 2018;6:e4483.

6. Siegers CP, von Hertzberg-Lottin E, Otte M, Schneider B. Anthranoid laxative abuse-a risk for colorectal cancer? Gut 1993;34:1099-1101.

7. Van Gorkom BAP, DeVries EGE, Karrenbeld A, Kleibeuker JH. Anthranoid laxatives and their potential carcinogenic effects. Aliment Pharmacol Ther 1999;13:443-452

8. Liu ZH, Foo DCC, Law WL, Chan FSY, Fan JKM, Peng JS. Melanosis coli: Harmless pigmentation? A case-control retrospective study of 657 cases. PLoS One 2017;12:e0186668.

9. Nusko G, Schneider B, Ernst H, Wittekind C, Hahn EG. Melanozis coli-a harmless pigmentation or a precancerous condition? Z Gastroenterol 1997:35:313-318.

10. Abu Baker F, Mari A, Feldman D, Suki M, Gal O, Kopelman Y. Melanosis Coli: A Helpful Contrast Effect or a Harmful Pigmentation? Clin Med Insights Gastroenterol 2018;11:1-5. 